ORIGINAL ARTICLE

\title{
A population based study of reporting patterns and characteristics of men who abuse their female partners
}

\author{
C Peek-Asa, C Zwerling, T Young, A M Stromquist, L F Burmeister, J A Merchant
}

Injury Prevention 2005;11:180-185. doi: 10.1136/ip.2004.006247

See end of article for authors' affiliations

.....................

Correspondence to:

Professor C Peek-Asa,

University of lowa College

of Public Health, 100

Oakdale Campus. \#114

IREH, lowa City, IA 52242-

5000; corinne-peek-asa@

viowa.edu

Accepted 15 January 2005

\begin{abstract}
Objective: This study estimates the prevalence of male abusive behavior reported by men and their female partners and identifies characteristics of abusive men.

Design: Baseline survey from a population based cohort study of general health.

Setting: A rural county in lowa, USA.

Subjects: 572 men and their cohabitating female partners.

Main outcome measures: Male-to-female physical, emotional, and sexual abuse reported by either partner.

Results: In this cohort, $13.6 \%$ of men had performed at least one act of physical abuse and $34.9 \%$ emotional abuse. More than $45 \%$ of abusive men reported their own behaviors. Alcohol problems, antisocial personality characteristics, depressive symptoms, and financial stress were all positively associated with both physical and emotional abuse, but suicidal thoughts were less likely among abusers. Conclusion: Identification of common characteristics of abusive men may predict proclivity towards partner violence and barriers to behavior modification.
\end{abstract}

$\mathrm{T}$ he body of research literature on intimate partner violence has grown considerably over the last several years. Although victimization has been reported by both men and women, ${ }^{12}$ most research has focused on female victims because females suffer more severe physical consequences. ${ }^{3}$ Many studies have identified the prevalence of victimization through interviews with female victims, both in the general population and in medical settings, and have established intimate partner violence as a public health priority. The National Crime Victimization Survey estimates that six per 1000 women are victims of intimate partner violence each year. ${ }^{4}$ Screenings in medical care settings indicate that between $12 \%$ and $30 \%$ of women receiving medical treatment report violence in their relationships within the past year. ${ }^{5-9}$ Other studies have helped identify characteristics of abused women with the goal of improved screening and service provision for victims. Screening for victimization has occurred primarily in the healthcare setting because it provides an efficient environment for identification and potentially for intervention. ${ }^{81011}$ Most of these studies have been conducted in urban populations, but the few studies that have examined rural populations find an equally high prevalence of abuse. ${ }^{1}$

Few studies have identified the prevalence of abusive behavior as reported by men. Research on abusive men has focused on men who have been incarcerated for domestic abuse, enrolled in mandated treatment programs because of an abuse arrest, or who have sought independent treatment. These are likely to be the most severe abusers. This research has identified the characteristics of abusive men to include emotional problems such as depression, aggression and hostility, ${ }^{12-15}$ personality disorders such as antisocial and borderline personality, ${ }^{16-19}$ a history of witnessing or being a victim of violence, ${ }^{2021}$ alcohol use, $^{15}{ }^{1822-24}$ and suicidal ideation. ${ }^{25}$ Financial stress has been identified as a common marital stressor and has been linked with marital aggression $^{26}$ and partner homicide. ${ }^{27}$ Other studies have compared maritally violent to generally violent men and found that they have similar characteristics. ${ }^{28}$ However, most studies found that abusive behaviors were not limited to men with any of these characteristics, and other studies found no associations with some or all of these items. ${ }^{21} 29$

The objectives of this research are to estimate the prevalence of abusive behavior among men in a rural population of cohabitating couples, and to identify if alcohol problems, depressive symptoms, antisocial personality tendencies, financial stress, and suicidal ideation are associated with abusive behavior. Defining the reported prevalence and personality characteristics of abusive men may help focus screening efforts for perpetrators and assist in the design of both individual and societal level intervention efforts. ${ }^{30}$ Furthermore, it will be helpful to identify appropriate environments in which to screen and refer men to treatment programs.

\section{METHODS}

\section{Study population}

The study population includes men living with female partners who participated in a population based longitudinal cohort study in a rural county. ${ }^{31}$ Cohort participants were selected from a complete county census. All information from this study was taken from the initial baseline assessment. The county has a population of 11624 and is entirely rural according to US Census Bureau definition (towns with fewer than 2500 residents).

Of the 2496 eligible households in the county, 1675 $(67.1 \%)$ agreed to participate or be contacted about future participation in the cohort. Households were enrolled until the desired sample size of 1000 was attained. The first round of cohort interviews included 1633 adults in 1004 households. A post-enumeration survey of 200 non-participating households found that participating and non-participating households were similar. ${ }^{31}$ This study was approved by the University of Iowa Human Subject Protection Committee.

Cohort members came to a research facility located in the county seat for medical evaluations and personal interviews between June 1994 and December 1997. All respondents aged 18 years and older were asked whether they were currently living with a spouse or partner. Only those who answered "yes" were asked to complete the questions about intimate 
partner violence. Participants were interviewed alone in a private room, without their partner present. The abuse questions were embedded in a lengthy questionnaire that included multiple health related questions.

Of the adult sample of $1633,1310(80.2 \%)$ were living with partners and completed the intimate partner violence items. This included responses from both members of 572 couples. Of these 572 couples, all responded to the questions about physical abuse and $570(99.7 \%)$ responded to questions about emotional abuse.

\section{Variables}

Two measures were used to identify the presence of abuse during the 12 months before the interview. Physically abusive acts were identified using the Conflict Tactics Scale. $^{32}$ As recommended by Straus, ${ }^{1}$ we used eight items from the 13 item scale to measure physical abuse (table 1).

Emotionally abusive acts were identified using Yllo's Controlling Behavior Questions, which were designed to measure ways in which an individual feels controlled by their partner. $^{33}$

Both men and their partners answered abuse questions. Abusive behavior could be identified by the man only, his partner only, or by both partners. If either partner reported abusive behavior on any of the items, the man was considered positive for abuse. The frequency of abuse was measured as the most frequent reported by either partner.

Men who had three or more positive responses on the CAGE questionnaire were considered to have a potential alcohol problem. ${ }^{34-36}$ Depressive symptoms were measured using the 11 item short version of the CES-D Depression Scale. Men with a score of eight or more were considered to have depressive symptoms. ${ }^{37} 38$ Antisocial personality characteristics were considered present for men who had at least four positive responses using a list of 10 questions that asked about behavior after the age of 15. These questions were adapted directly from the University of Michigan Survey Research Center's National Survey of Health and Stress, 1990-1992 and based on the Diagnostic Interview Schedule from the DSM-III criteria. Financial stress was measured as a positive response to either going deeply into debt or having a substantially decreased income over the last year. Suicidal thoughts were ascertained by asking the respondent if they had made plans to take their own life or had attempted to take their own life in the past year.

\section{Data analysis}

Multivariable logistic regression analysis was first conducted to estimate the effect of the independent variables on the likelihood of each type of abuse as well as the combination of physical and emotional abuse. Next, multivariate logistic models were run to estimate the odds ratios of the independent variables on physical and emotional abuse as reported by men and their female partners. All models controlled for age and education of the man, which were the only sociodemographic variables related to abuse in crude analyses. Hoesmer-Lemeshow goodness of fit and likelihood ratio tests were used to evaluate the appropriateness of each model. ${ }^{39}$ Models were run in SAS version 8.0 (SAS Institute Inc, Cary, NC, USA).

\section{RESULTS}

In this cohort of rural men living with their partners, $13.6 \%$ had performed at least one act of physical abuse and 34.9\% had performed at least one act of emotional abuse (table 1). The majority of physically abusive events occurred only once during the 12 month reporting period and the majority of respondents reported no more than two types of event. Pushing, grabbing, or shoving $(9 \%)$ was the most common

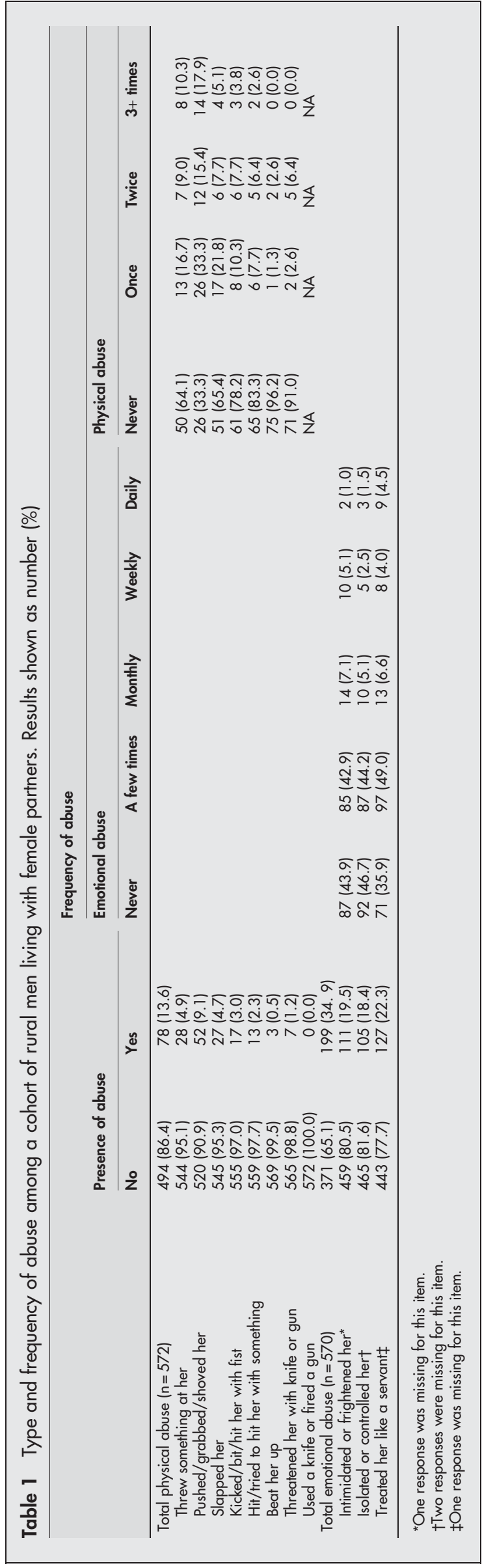


Table 2 Identification of physical and emotional abuse by a cohort of rural men and their female partners

\begin{tabular}{|c|c|c|}
\hline & $\begin{array}{l}\text { Physical abuse, } \\
\text { n (\%) }\end{array}$ & $\begin{array}{l}\text { Emotional abuse, } \\
\text { n (\%) }\end{array}$ \\
\hline No abuse & $494(86.4)$ & $371(65.1)$ \\
\hline Any abuse & 78 (13.6) & 199 (34.9) \\
\hline $\begin{array}{l}\text { Abuse identified by self } \\
\text { only }\end{array}$ & 12 (15.4) & $31(15.6)$ \\
\hline $\begin{array}{l}\text { Abuse identified by } \\
\text { partner only }\end{array}$ & $43(55.1)$ & $63(31.7)$ \\
\hline Abuse identified by both & $23(29.5)$ & $105(52.8)$ \\
\hline
\end{tabular}

physical act, followed by throwing something (5\%) and slapping (5\%), although throwing something was more often a repeated behavior than slapping. Beating up his partner $(0.5 \%)$ and threatening her with a knife or gun $(1.2 \%)$ were the least reported physical acts, and no respondents reported using a knife or a gun.

Treating his partner like a servant was the most common type of emotionally abusive behavior (22.3\%), although all three types of emotional abuse were common. Approximately $1 \%$ of men emotionally abused their partners daily. Fifty one men $(8.9 \%)$ were both physically and emotionally abusive, whereas $27(4.7 \%)$ men were physically abusive only and 148 (25.8\%) men were emotionally abusive only.

Abusive men could be identified by themselves, their partners, or both (table 2). Any positive response was considered as abuse. Among physical abusers, 12 (15.4\%) were identified by themselves only, 43 (55.1\%) were identified by their partners only, and 23 (29.5\%) were identified by both. Thus, $44.9 \%$ of physical abusers were self identified. Among emotional abusers, 31 (15.6\%) were identified by themselves only, $63(31.7 \%)$ by their partners only, and $105(52.8 \%)$ by both. A total of $68.3 \%$ of emotional abusers were self identified. Disagreement in response between couples was higher for physical than emotional abuse. While approximately $15 \%$ of both physical and emotional abusers were identified only by themselves, $55.1 \%$ of physical and $31.7 \%$ of emotional abusers were identified only by their partners.

Both physically and emotionally abusive men had a younger age distribution than non-abusive men, although at least $10 \%$ of men in all age groups had abusive behaviors (table 3). Abuse peaked between the ages of 35 and 44, in which more than $35 \%$ of men perpetrated each type of abuse. Both physical and emotional abusers were married a shorter period of time than non-abusers, which is consistent with the relationship between younger age and abuse. Physically, but not emotionally abusive men had a significantly earlier age at first marriage.

Children from birth through age nine were present in $41.0 \%$ of homes with physically abusive men and $32.2 \%$ of homes with emotionally abusive men. Homes with abusive men were significantly more likely to have children present than homes of non-abusers.

After controlling for age and education, alcohol problems, antisocial personality characteristics, depressive symptoms, and financial problems were all associated with increased physical and emotional abuse (table 4). Men who had suicidal thoughts or actions were less likely to be either physically or emotionally abusive than men who did not. The magnitude of effect was greater for emotional than physical abuse for all covariates, but confidence intervals covered similar ranges for alcohol problems and antisocial personality characteristics. Men with depressive symptoms, however, were 3.2 (95\% CI 1.9 to 5.4 ) times more likely to be emotionally abusive and 1.8 (95\% CI 0.9 to 3.3 ) times more likely to be physically abusive than men who did not report depressive symptoms.

Men with antisocial personality characteristics were 3.3 (95\% CI 1.5 to 7.6 ) times more likely to exhibit both types of abusive behavior than men without these characteristics, and this exceeded the independent magnitude of effect for physical (OR $=2.2 ; 95 \%$ CI 1.0 to 4.8$)$ and emotional (OR 2.7; $95 \%$ CI 1.3 to 5.7 ) abuse. Men with alcohol problems were also more likely to perform both types of abusive acts.

\begin{tabular}{|c|c|c|c|c|c|c|}
\hline \multirow[b]{2}{*}{ Characteristic } & \multicolumn{3}{|c|}{ Physical abuse } & \multicolumn{3}{|c|}{ Emotional abuse } \\
\hline & $\begin{array}{l}\text { Abuser, } \\
\mathrm{n}(\%)\end{array}$ & $\begin{array}{l}\text { Non-abuser, } \\
\mathrm{n}(\%)\end{array}$ & p Valuet & $\begin{array}{l}\text { Abuser, } \\
\mathrm{n}(\%)\end{array}$ & $\begin{array}{l}\text { Non-abuser, } \\
\mathrm{n}(\%)\end{array}$ & p Valuet \\
\hline \multicolumn{7}{|l|}{ Age (years) } \\
\hline $18-34^{*}$ & $15(19.2)$ & $32(6.5)$ & & $29(14.6)$ & $18(4.9)$ & \\
\hline $35-44$ & $31(39.7)$ & $118(23.9)$ & & 70 (35.2) & 79 (21.3) & \\
\hline $45-54$ & $13(16.7)$ & $98(19.8)$ & & $40(20.1)$ & $71(19.1)$ & \\
\hline $55-64$ & $9(11.5)$ & $97(19.6)$ & & $26(13.1)$ & $80(21.6)$ & \\
\hline $65+$ & $10(12.8)$ & $149(30.2)$ & $<0.01$ & $34(17.1)$ & $123(33.2)$ & $<0.01$ \\
\hline \multicolumn{7}{|l|}{ Educational status } \\
\hline High school incomplete & $6(7.7)$ & $57(11.6)$ & & $18(9.1)$ & 45 (12.2) & \\
\hline High school & $32(41.0)$ & $239(48.6)$ & & $80(40.2)$ & $189(51.2)$ & \\
\hline Some college or more & $40(51.3)$ & $196(39.8)$ & 0.15 & $101(50.8)$ & $135(36.6)$ & $<0.01$ \\
\hline \multicolumn{7}{|l|}{ Household location } \\
\hline Farm & $26(33.3)$ & $186(37.7)$ & & $60(30.1)$ & $150(40.4)$ & \\
\hline Rural non-farm & $20(25.6)$ & 95 (19.2) & & $40(20.1)$ & 75 (20.2) & \\
\hline Town & $32(41.0)$ & $213(43.1)$ & 0.41 & $99(49.8)$ & $146(39.4)$ & 0.31 \\
\hline \multicolumn{7}{|l|}{ Married } \\
\hline Yes & 72 (92.3) & $478(96.8)$ & & $189(95.0)$ & $359(96.8)$ & \\
\hline No & $6(7.7)$ & $16(3.2)$ & 0.10 & $10(5.0)$ & $12(3.2)$ & 0.29 \\
\hline Average years married & 20.03 & 28.31 & $<0.01$ & 22.11 & 29.82 & $<0.01$ \\
\hline $\begin{array}{l}\text { Average age married } \\
\text { Children 0-9 }\end{array}$ & 24.83 & 26.20 & 0.017 & 25.73 & 26.13 & 0.63 \\
\hline Yes & $32(41.0)$ & $97(19.6)$ & & $64(32.2)$ & 65 (17.5) & \\
\hline No & $46(59.0)$ & $397(80.4)$ & $<0.01$ & $135(67.8)$ & $306(82.5)$ & $<0.01$ \\
\hline
\end{tabular}

*Only three men were in the age group 18-24, so this group was combined with 25-34. $\mathrm{tp}$ Values represent two sided $t$ tests for continuous variables, Fisher's exact test for categorical variables with any cell size less than 10 , and $\chi^{2}$ tests for categorical variables with all cell sizes of 10 or above. 
Table 4 Characteristics of abusive behavior among a cohort of rural married men

\begin{tabular}{|c|c|c|c|c|c|c|c|}
\hline \multirow[b]{2}{*}{ Characteristic } & \multicolumn{3}{|c|}{ Physical abuse } & \multicolumn{3}{|c|}{ Emotional abuse } & \multirow{2}{*}{$\begin{array}{l}\text { Odds of both } \\
\text { emotional and } \\
\text { physical abuse* }\end{array}$} \\
\hline & $\begin{array}{l}\text { Non-abuser, } \\
\text { n (\%) }\end{array}$ & $\begin{array}{l}\text { Abuser, } \\
\text { n (\%) }\end{array}$ & $\mathrm{OR}^{*}(95 \% \mathrm{Cl})$ & $\begin{array}{l}\text { Non-abuser, } \\
\text { n (\%) }\end{array}$ & $\begin{array}{l}\text { Abuser, } \\
\text { n (\%) }\end{array}$ & $\mathrm{OR}^{*}(95 \% \mathrm{Cl})$ & \\
\hline \multicolumn{8}{|c|}{ Alcohol problems } \\
\hline Yes & $30(6.7)$ & $9(12.3)$ & $1.86(0.82-4.21)$ & $18(5.4)$ & $21(11.3)$ & $2.11(1.07-4.15)$ & $2.27(0.91-5.65)$ \\
\hline No & 415 (93.3) & $64(87.7)$ & 1.00 & $312(94.6)$ & 165 (88.7) & 1.00 & 1.00 \\
\hline \multicolumn{8}{|c|}{$\begin{array}{l}\text { Antisocial personality } \\
\text { characteristics }\end{array}$} \\
\hline Yes & $25(5.1)$ & $11(14.1)$ & $2.20(1.01-4.80)$ & $13(3.5)$ & $23(11.6)$ & $2.74(1.33-5.66)$ & $3.33(1.46-7.61)$ \\
\hline No & $469(94.9)$ & $67(85.9)$ & 1.00 & $358(96.5)$ & $176(88.4)$ & 1.00 & 1.00 \\
\hline \multicolumn{8}{|c|}{ Depressive symptoms } \\
\hline Yes & $60(12.1)$ & $16(20.5)$ & $1.75(0.93-3.30)$ & $30(8.1)$ & $44(22.1)$ & $3.23(1.93-5.42)$ & $2.38(1.71-4.82)$ \\
\hline No & $434(87.9)$ & $62(79.5)$ & 1.00 & $341(91.9)$ & $155(77.9)$ & 1.00 & 1.00 \\
\hline \multicolumn{8}{|c|}{ Financial problems $\dagger$} \\
\hline Yes & $92(18.7)$ & $20(25.6)$ & $1.36(0.77-2.42)$ & $61(16.5)$ & $51(25.6)$ & $1.62(1.06-2.51)$ & $1.49(0.76-2.91)$ \\
\hline No & $399(81.3)$ & 58 (74.4) & 1.00 & 308 (83.5) & 148 (74.4) & 1.00 & 1.00 \\
\hline \multicolumn{8}{|c|}{ Suicidal thoughts } \\
\hline Yes & $35(7.1)$ & $13(16.7)$ & $0.36(0.18-0.74)$ & $19(5.1)$ & $29(14.6)$ & $0.28(0.15-0.53)$ & $0.25(0.12-0.55)$ \\
\hline No & $459(92.9)$ & 65 (83.3) & 1.00 & $352(94.9)$ & $170(85.4)$ & 1.00 & 1.00 \\
\hline
\end{tabular}

Trends persisted when examining abuse reported by the man or by the woman (table 5). For physical abuse reported by men, antisocial personality characteristics were 3.1 (95\% CI 1.1 to 8.5) times more frequent among abusers than nonabusers, while for physical abuse reported by the woman the odds ratio was 2.3 (95\% CI 1.0 to 5.2). Depressive symptoms, however, had a slightly stronger association with emotional abuse reported by the woman than by the man (woman, OR $3.5,95 \%$ CI 2.1 to 6.0 ; man, OR $2.9,95 \%$ CI 1.6 to 5.1 ).

\section{DISCUSSION}

The prevalence of male intimate partner violence reported simultaneously by men and their partners has not been widely measured. In a population based sample of physical abuse, Schafer et al found the prevalence of male-to-female partner violence reported by both partners to be $13.6 \%$, which is identical to the total prevalence of $13.6 \%$ in this sample. ${ }^{40}$ We included all acts of physical abuse, and this prevalence is higher than studies that only included severe abuse. We found that $45 \%$ of physically abusive men and over two thirds of emotionally abusive men did report their acts of abuse. Approximately $15 \%$ of abusive behavior was reported by the men but not their partners. In comparison, Schafer et al found that a total of $67.9 \%$ of abusive men reported their behavior, with $28 \%$ of physical abuse reported by men but not their partners. ${ }^{40}$ These findings indicate that many abusive men do report their behavior in a confidential, structured survey.

In this population based cohort of men, abusers had many of the same characteristics identified through studies of men who had been arrested or treated for abusive behavior. These included increased likelihood of alcohol problems, depressive symptoms, and antisocial personality characteristics. Financial stress was also related to abuse, and financial stress has been identified as one of the most commonly reported stressors in marriages. ${ }^{26}{ }^{27}$ We found that abusive men were less likely to have suicidal ideation than nonabusive men. One previous study, however, found that suicide was more likely among abusive men, and increased with increasing severity of abuse. ${ }^{25}$ Suicidal ideation may thus be associated only with very severe abuse. The relevance of personality disorders in understanding male intimate partner abuse has been long debated, ${ }^{30}$ and our data indicate that such differences persist in a population based sample.

Past research has focused on physical abuse, often because the studies included men who were arrested for their behavior, and arrest is usually the result of physical assault. However, covariates in this study had stronger associations

Table 5 Characteristics of physical and emotional abuse among a cohort of rural married men

\begin{tabular}{|c|c|c|c|c|}
\hline \multirow[b]{2}{*}{ Characteristic } & \multicolumn{2}{|l|}{ Physical abuse } & \multicolumn{2}{|l|}{ Emotional abuse } \\
\hline & $\begin{array}{l}\text { Odds of physical } \\
\text { abuse when abuse } \\
\text { was reported by the } \\
\text { man* } \dagger(95 \% \mathrm{Cl})\end{array}$ & $\begin{array}{l}\text { Odds of physical } \\
\text { abuse when abuse } \\
\text { e was reported by the } \\
\text { woman* } \ddagger(95 \% \mathrm{Cl})\end{array}$ & $\begin{array}{l}\text { Odds of emotional } \\
\text { abuse when abuse } \\
\text { was reported by the } \\
\text { man* } \dagger(95 \% \mathrm{Cl})\end{array}$ & $\begin{array}{l}\text { Odds of emotional } \\
\text { abuse when abuse was } \\
\text { e reported by the } \\
\text { woman* } \ddagger(95 \% \mathrm{Cl})\end{array}$ \\
\hline Alcohol problems & $2.53(0.90-7.10)$ & $2.22(0.97-5.08)$ & $1.85(0.86-4.0)$ & $2.10(1.04-4.25)$ \\
\hline $\begin{array}{l}\text { Antisocial personality } \\
\text { characteristics }\end{array}$ & $y_{3.11(1.14-8.46)}$ & $2.32(1.02-5.24)$ & $2.82(1.29-6.15)$ & $2.77(1.31-5.85)$ \\
\hline $\begin{array}{l}\text { Depressive symptoms } \\
\text { Financial problems§ } \\
\text { Suicidal thoughts }\end{array}$ & $\begin{array}{l}\text { s } 1.75(0.73-4.21) \\
1.62(0.75-3.53) \\
0.44(0.16-1.21)\end{array}$ & $\begin{array}{l}1.83(0.93-3.58) \\
1.47(0.80-2.70) \\
0.32(0.15-0.68)\end{array}$ & $\begin{array}{l}2.89(1.60-5.08) \\
1.81(1.12-2.93) \\
0.23(0.12-0.46)\end{array}$ & $\begin{array}{l}3.52(2.06-6.02) \\
1.69(1.07-2.66) \\
0.26(0.14-0.50)\end{array}$ \\
\hline \multicolumn{5}{|c|}{$\begin{array}{l}\text { *All models were controlled for age and educational status. } \\
\text { †Compares couples in which the man identified battering behavior with couples in which neither partner identified } \\
\text { battering. } \\
\text { †Compares couples in which the woman identified battering behavior with couples in which neither partner } \\
\text { identified battering. } \\
\text { §Financial problems are defined as either going deeply into debt or income substantially decreasing in the last } \\
\text { year. }\end{array}$} \\
\hline
\end{tabular}


with emotional than physical abuse, which suggests that the causal pathways of emotional and physical abuse may be similar.

Although trends in the relations between the covariates and physical and emotional abuse were consistent, the magnitude of effect varied based on whether the behavior was reported by the man himself or by his partner. Antisocial personality characteristics were more strongly associated with abuse reported by the man himself, whereas depressive symptoms were more strongly related to abuse reported by the woman. Men who have antisocial personality characteristics may be less influenced by external attitudes towards their behavior, and thus may have fewer internal incentives to hide abusive behavior. Psychological research has described the abusive man with antisocial tendencies as initially charismatic, but who expresses violence and intimidation when the relationship becomes intimate and his sense of control threatened. ${ }^{18}$ This threat is typically based on the abuser's distorted interpretation of the relationship and often his inability to empathize with his partner. As a result, he may interpret his battering behavior to be appropriate and thus be willing to report it.

This study was conducted in a rural population. Although research has shown the prevalence of intimate partner abuse to be similar in rural and urban populations, ${ }^{1}$ rural populations may have unique risk factors and challenges to intervention. ${ }^{41-43}$ Many batterers impose isolation on their victims, and this is a greater problem when the couple live in a physically isolated area. In isolated settings, batterers can more easily hide abusive acts. Attitudes of individuals, medical care providers, and law enforcement as they relate to gender roles and privacy have also been identified as impediments to preventing partner abuse in rural counties. ${ }^{41-43}$

One important finding of this research is that $41 \%$ of homes with physically and $32 \%$ of homes with emotionally abusive men had young children in the household. Some of this relationship may be attributed to the tendency for batterers to be younger. However, these findings indicate that many rural children are at risk of witnessing abusive behavior. Numerous studies have identified the relation between witnessing and experiencing violence as a child and adult abusive behavior and victimization. ${ }^{44-46}$ These children may be at increased risk for learned violent behavior. ${ }^{47} 48$

This study has several limitations. Information about abusive behavior and associated covariates is cross sectional, so the time sequencing between the onset of abuse and the associated characteristics of abusive men cannot be determined. Causal connections are thus speculative. The sample size of abusive men, especially physical abusers, was not large enough to identify interactions between covariates. The sample included only men who were living with female partners and may not represent men in other types of relationships. This sample included inhabitants of a rural county who may not be representative of urban couples.

This study also has a number of important strengths. To our knowledge, this is the first population based study that has identified characteristics of abusive men currently living with female partners. It is also one of few population based studies to compare reports of male abusive behavior between men and their partners. ${ }^{40}$ Because the data come from the baseline assessment of a longitudinal study, analyses of behavior changes over time will be possible.

\section{CONCLUSION}

Evaluations of batterer treatment programs have shown limited success, ${ }^{9}{ }^{49}$ and this may be an indication that behavior modification programs need to be better designed to address specific personality characteristics of abusive men. ${ }^{30}$ Evaluation efforts need to address the relative success

\section{Key points}

- Few studies have examined characteristics of abusive men using a population based cohort. In this population based cohort of rural men, $13.6 \%$ had performed at least one act of physical abuse and $34.9 \%$ had performed at least one act of emotional abuse.

- Through this in-person interview, many men did report their own acts of abuse. Of all abuse reported by either partner, $45 \%$ of physically abusive men and over two thirds of emotionally abusive men reported their own acts of abuse.

- Alcohol problems, antisocial personality characteristics, depressive symptoms, and financial problems were all associated with increased physical and emotional abuse by men. Point estimates were higher for emotional than physical abuse.

- Male abusers have many problematic personality characteristics, and these may hinder the success of behavioral interventions.

of different interventions, contrasting those at the individual and those at the community level. Some men, such as those who do not identify their abusive behavior, may be less amenable to counselling based treatment programs and may need stronger external pressure and incentives to stop their behavior. Prevention efforts that focus on behavior modification of the abusive male should recognize that these characteristics may be present in many of their subjects, and apply appropriate behavioral approaches. Finally, the appropriateness of the medical setting to screen and refer abusive men to treatment programs should be explored.

\section{Authors' affiliations}

C Peek-Asa, C Zwerling, T Young, The University of lowa Injury Prevention Research Center, College of Public Health, Department of Occupational and Environmental Health, lowa City, IA, USA

A M Stromquist, L F Burmeister, J A Merchant, The University of lowa Great Plains Center for Agricultural Health, College of Public Health, Department of Occupational and Environmental Health, lowa City, IA, USA

\section{REFERENCES}

1 Murty S, Peek-Asa C, Zwerling C, et al. Physical and emotional partner abuse reported by men and women in a rural community. Am J Public Health 2003;93:1073-5.

2 Straus MA. Measuring intrafamily conflict and violence: The Conflict Tactics (CT) Scales. In Straus MA, Gelles RJ, eds. Physical violence in American families: risk factors and adaptations to violence in 8145 families. New Brunswick, NJ: Transaction Books, 1990:29-47.

3 Archer J. Sex differences in aggression between heterosexual partners: a meta-analytic review. Psychol Bull 2000;126:651-80.

4 Rennison CM. Intimate partner violence and age of victim, 1993-1999. Bureau of Justice Statistics Special Report. Washington DC: US Department of Justice, 2001, NCJ 187535.

5 Johnson M, Elliott BA. Domestic violence among family practice patients in midsized and rural communities. J Fam Pract 1997;44:391-400.

6 Coker AL, Smith PH, Bethea L, et al. Physical health consequences of physical and psychological intimate partner violence. Arch Fam Med 2000;9:451-7.

7 Anglin D, Sachs C. Preventive care in the emergency department: screening for domestic violence in the Emergency Department. Acad Emerg Med 2003;10:1118-27.

8 Tiaden $\mathbf{P}$, Thoennes $\mathrm{N}$. Full report of the prevalence, incidence and consequences of violence against women: research report. Washington, DC: National Institute of Justice, 2000, NCJ 183781

9 Wathen CN, MacMillan HL. Interventions for violence against women: scientific review. JAMA 2003;289:589-600.

10 McNutt $L$, Carlson BE, Rose IM, et al. Partner violence intervention in the busy primary care environment. Am J Prev Med 2002;22:84-91.

11 Rhodes KV, Levinson W. Interventions for intimate partner violence against women: clinical applications. JAMA 2003;289:601-5. 
12 Barnett OW, Fagan RW. Alcohol use in male spouse abusers and their female partners. J Fam Violence 1993;8:1-25.

13 Barnett OW, Hamberger LK. The assessment of maritally violent men on the California Psychological Inventory. Violence Vict 1992;7:15-28.

14 Pan H, Neidig P, O'Leary D. Predicting mild and severe husband to wife physical aggression. J Consult Clin Psychol 1994;62:975-81.

15 Sugihara Y, Warner J. Mexican-American male batterers on the MCMI-III. Psychol Rep 1999;85:663-9.

16 Gortner ET, Gollan JK, Jacobson NS. Psychological aspects of perpetrators of domestic violence and their relationship with the victims. Psychiatr Clin North Am 1997;20:337-52.

17 Hamberger LK, Hastings J. Characteristics of male spouse abusers consistent with personality disorders. Hosp Community Psychiatry 1988;39:763-70.

18 Hastings JE, Hamberger LK. Personality characteristics of spouse abusers: a controlled comparison. Violence Vict 1988;3:31-48.

19 Holtzworth-Munroe A, Stuart GL. Typologies of male batterers: three subtypes and the differences among them. Psychol Bull 1994;1 16:476-97.

20 Barnett OW, Fagan RW, Booker JM. Hostility and stress as mediators of aggression in violent men. J Fam Violence 1991;6:217-41.

21 Bergman BD, Brismar BG. Can family violence be prevented? A psychosocial study of male batterers and battered wives. Public Health 1992;106:45-52.

22 Cunradi CB, Caetano R, Schafer J. Alcohol-related problems, drug use, and male intimate partner violence severity among US couples. Alcohol Clin Exp Res 2002;26:493-500.

23 Fagan RW, Barnette OW, Patton JB. Reasons for alcohol use in maritally violent men. Am J Drug Alcohol Abuse 1988;14:371-92.

24 Stuart GL, Moore TM, Kahler CW, et al. Substance abuse and relationship violence among men court-referred to batterers' intervention programs. Subst Abus 2003;24:107-22

25 Conner KR, Cerulli C, Caine, eds. Threatened and attempted suicide by partner-violent male respondents petitioned to family violence court. Violence \& Victims 2002;17:115-25.

26 Margolin G Gordis EB. Co-occurrence between marital aggression and parents' child abuse potential: the impact of cumulative stress. Violence \& Victims 2003; 18:243-58.

27 Milroy CM, Dratsas M, Ranson DL. Homicide-suicide in Victoria, Australia. Am J Forensic Med Pathol 1997;18:369-73.

28 Maiuro RD, Cahn TS, Vitaliano PP, et al. Anger, hostility, and depression in domestically violent versus generally assaultive men and nonviolent control subjects. J Consult Clin Psychol 1988;56:17-23.

29 Neidig P, Friedman D, Collins B. Attitudinal characteristics of males who have engaged in spouse abuse. J Fam Violence 1986;1:223-33.

30 Holtzworth-Munroe A, Meehan JC. Husband violence: personality disorders among male batterers. Curr Psychiatry Rep 2002;4:13-17.
31 Merchant JA, Stromquist AM, Kelly KM, et al. Chronic disease and injury in an agricultural county. J Rural Health 2002;18:521-35.

32 Straus MA. Measuring intrafamily conflict and violence: The Conflict Tactics (CT) Scale. J Marriage Fam 1979:41:74-85.

33 Yllo K. Political and methodological debates in wife abuse research. In: Yllo K, Bograd M, eds. Feminist perspectives on wife abuse research. Newbury Park, CA: Sage, 1990:28-50.

34 Buchsbaum DG, Buchanan RG, Centor RM, et al. Screening for alcohol abuse using CAGE scores and likelihood ratios. Ann Intern Med 1991;155:774-7.

35 Ewing JA. Detecting alcoholism: the CAGE questionnaire. JAMA 1984;252:1905-7.

36 Mayfield DG, McLeod G, Hall P. The CAGE questionnaire: validation of a new alcoholism screening instrument. Am J Psychiatry 1974;131:1121-3.

37 Kohout FJ, Berkman LF, Evans DA, et al. Two shorter forms of the CES-D Depression Symptoms Index. J Aging Health 1993;5:179-93.

38 Radloff LS. The CES-D scale: a self-report depression scale for research in the general population. Appl Psychol Meas 1977;1:385-401.

39 Hosmer DW, Lemeshow. Applied Logistic Regression. New York, New York: Wiley and Sons, 1989.

40 Schafer J, Caetano R, Clark CL. Rates of intimate partner violence in the United States. Am J Public Health 1998;88:1702-4.

41 Goeckermann CR, Hamberger LK, Barber K. Issues of domestic violence unique to rural areas. Wis Med J 1994;93:473-9.

42 Van Hightower NR, Gorton J. Domestic violence among patients at two rural health care clinics: prevalence and social correlates. Public Health Nurs 1998; 15:355-62.

43 Kershner M, Anderson JE. Barriers to disclosure of abuse among rural women. Minn Med 2002;85:32-7.

44 Castro RP, Peek-Asa C, Ruiz A. Violence against women in Mexico: a study of abuse before and during pregnancy. Am J Public Health 2003;93:1110-16.

45 Kalmuss $D$. Intergenerational transmission of marital aggression. J Marriage Fam 1984;46:11-19.

46 Holtzworth-Munroe A, Saunders DG. Men who batter: recent history and research. Violence Vict 1996;11:273-6.

47 Dube SR, Anda RF, Felitti VJ, et al. Exposure to abuse, neglect, and household dysfunction among adults who witnessed intimate partner violence as children: implications for health and social services. Violence Vict 2002;17:3-17.

48 Levendosky AA, Huth-Bocks A, Semel MA. Adolescent peer relationships and mental health functioning in families with domestic violence. J Clin Child Adolesc Psychol 2002;31:206-18.

49 Jackson S, Feder L, Forde DR, et al. Batterer intervention programs: where do we go from here?. National Institute of Justice, US Department of Justice, June 2003: NCJ 195079 